Studia nad Autorytaryzmem i Totalitaryzmem 42, nr 2

Wrocław 2020

https://doi.org/10.19195/2300-7249.42.2.7

PAWEŁ JABŁOŃSKI

ORCID: 0000-0002-9562-4419

Uniwersytet Wrocławski

pawel.jablonski@uwr.edu.pl

\title{
Formuła Radbrucha w świetle krytyki Herberta L.A. Harta
}

\begin{abstract}
Abstrakt: Celem artykułu jest analiza formuły Radbrucha z punktu widzenia krytyki przeprowadzonej przez Herberta L.A. Harta. Na użytek niniejszego tekstu wyróżniam dwa podstawowe argumenty obecne w rozważaniach Harta, które określam jako pojęciowy i empiryczny. Argument pojęciowy polega na wskazaniu, że nie należy mieszać problemu istnienia prawa z zagadnieniem jego przestrzegania. Argument empiryczny z kolei polega na zanegowaniu tego, że uległość społeczeństwa niemieckiego wobec zbrodniczych rządów Hitlera miała swoje źródło w przyjęciu pozytywistycznego sposobu myślenia.

Podstawowa hipoteza artykułu głosi, że między systemami teoretycznymi tych dwóch gigantów filozofii prawa zachodzą znacznie ciekawsze interakcje, niż by to wynikało z argumentów Harta. Co więcej, wydaje się, że napięcie między tymi dwoma sposobami myślenia nie musi być aż tak duże, jak przedstawia to autor Pojęcia prawa i jak to często się dziś przyjmuje.

Nakreślone wyżej zadanie realizuję w kilku krokach. Po uwagach wprowadzających porządkuję problem podstawy rekonstrukcji formuły Radbrucha. Następnie odtwarzam treść tej formuły, sygnalizując przy tym kilka wątpliwości interpretacyjnych. W dalszej kolejności rekonstruuję zarzuty podnoszone wobec niej przez Harta, proponując sprowadzenie ich do dwóch podstawowych. W kolejnych częściach tekstu podejmuję dyskusję z tymi argumentami oraz wskazuję pewną możliwość przekonfigurowania omawianego sporu.

Propozycja ta nawiązuje z jednej strony do prac Briana H. Bixa, a z drugiej do Kantowskiej figury współpracy rozumu teoretycznego i praktycznego. Jako to miejsce koncepcji Harta, w które można wpisać formułę Radbrucha, wskazuję regułę uznania. Autor Pojęcia prawa w swojej teorii nie rozstrzyga kształtu reguły uznania konkretnych porządków prawnych, a jedynie tworzy ogólny model teoretyczny. Nie wyklucza więc, że w jakimś porządku prawnym zaistnieje taka reguła uznania, która będzie łączyć się z kryterium moralnym. W tym momencie kończy się praca rozumu teoretycznego, a zaczyna praktycznego. Formułę Radbrucha można bowiem potraktować jako wynikający z traumatycznej sytuacji historycznej apel rozumu praktycznego, by włączyć klauzule łączone z tezą odmowy lub tezą lekceważenia do reguły uznania współczesnych porządków prawnych. Rozum praktyczny proponuje więc rozstrzygnięcie tego, co rozum teoretyczny pozostawia otwarte.
\end{abstract}

Słowa kluczowe: formuła Radbrucha, Hart, reguła uznania, rozum teoretyczny, rozum praktyczny. 


\title{
RADBRUCH'S FORMULA FROM THE PERSPECTIVE OF HERBERT L.A. HART'S CRITIQUE
}

\begin{abstract}
The aim of the article is the analysis of Radbruch's formula from the point of view of Herbert L.A. Hart's critique. For the purposes of this text, I distinguish two fundamental arguments present in Hart's considerations. I name them as a conceptual one and an empirical one. The conceptual argument claims that the problem of the existence of law should not be confused with the issue of following this law. The empirical argument consists in negating the claim that German society's submission to Hitler's criminal rules was rooted in adopting a positivist way of thinking.

The main hypothesis of this article claims that there are much more interesting interactions between the conceptions of these two giants of the philosophy of law than it would appear from Hart's arguments. Moreover, it seems that the tension between these two ways of thinking does not have to be as strong as the author of the Concept of Law presents, and how it is often claimed today.

I complete the task outlined above in a few steps. After introductory remarks, I resolve the problem of the basis for reconstruction of Radbruch's formula. Then I recreate the content of this formula, signalling some doubts in its interpretation. Next, I reconstruct the objections made by Hart against it, proposing to reduce them to two basic ones. In the following parts of the text, I discuss these arguments and formulate the proposal of reconfiguring the dispute.

This proposal refers on the one hand to the work of Brian H. Bix, and on the other hand to Kant's figure of cooperation between theoretical and practical reason. I indicate the rule of recognition as the place of Hart's concept in which Radbruch's formula can be entered. The author of the Concept of Law does not determine the shape of the rule of recognition in specific legal order, but only creates a general theoretical model. He does not exclude, therefore, that in some legal order there will be such a rule of recognition which is connected with the moral criterion. At this point, the work of theoretical reason is ending and the work of practical one is beginning . Radbruch's formula can be treated as an appeal of practical reason - resulting from a traumatic historical situation - to include its clauses into the rule of recognition. Practical reason therefore chooses one of the possibilities left by theoretical reason.
\end{abstract}

Keywords: Radbruch's formula, Hart, rule of recognition, theoretical reason, practical reason.

Charakterystyczne w oscylowaniu między ekstremami, tworzącymi historię teorii prawa, jest to, że ci, którzy widzieli w daleko idącym upodobnianiu prawa i moralności nie więcej niż mylne wnioskowanie $\mathrm{z}$ faktu, że podzielają one wspólny słownik uprawnień i powinności, protestowali przeciwko owemu upodobnianiu w sposób równie przesadzony i paradoksalny.

Herbert L.A. Hart ${ }^{1}$

${ }^{1}$ H.L.A. Hart, Pojęcie prawa, przeł. J. Woleński, Warszawa 1998, s. 21. 


\section{Uwagi wprowadzające}

Celem niniejszego artykułu jest przyjrzenie się krytyce, jaką Herbert Lionel Adolphus Hart przeprowadził w stosunku do konstruktu filozoficzno-prawnego, określanego mianem „formuły Radbrucha”. Zadanie to wydaje się warte podjęcia z dwóch przynajmniej powodów. Pierwszym z nich jest ciągła aktualność pytania o dopuszczalność przyjętego przez Gustava Radbrucha sposobu rozwiązania konfliktu między moralnością a prawem. Jako że interesująca nas tu formuła była aplikowana w praktyce stosowania prawa ${ }^{2}$, to rzeczona aktualność ma wymiar nie tylko teoretyczny, lecz również praktyczny ${ }^{3}$. W literaturze przedmiotu podkreśla się przy tym, że formuła ta może mieć znaczenie nie tylko w systemach totalitarnych, ale też $\mathrm{w}$ warunkach demokratycznego państwa prawa ${ }^{4}$. Drugim z powodów jest natomiast to, że w krytyce tej dochodzi do teoretycznego spotkania dwóch klasycznych dziś już myślicieli, których prace mają fundamentalne znaczenie dla kształtu współczesnej filozofii prawa. Jakkolwiek argumenty Harta zostały przedstawione już po śmierci Radbrucha, to da się poszukać w pracach niemieckiego autora możliwych kontrargumentów. Można przy tym pokusić się o hipotezę, że między systemami teoretycznymi tych dwóch gigantów filozofii prawa zachodzą znacznie ciekawsze interakcje, niż by to wynikało z argumentów Harta. Co więcej, wydaje się, że napięcie między tymi dwoma sposobami myślenia nie musi być aż tak duże, jak przedstawia to autor Pojęcia prawa i jak to często się dziś przyjmuje.

Uzyskanie przez Harta statusu autora najgłośniejszej krytyki formuły Radbrucha ${ }^{5}$ jest o tyle paradoksalne, że brytyjski filozof poświęca mu stosunkowo niewiele miejsca. W przywoływanym w tym kontekście słynnym artykule Pozytywizm i oddzielenia prawa od moralności przeznacza na to jedną z sześciu jego części ${ }^{6}$. Odwoływanie się do pism Radbrucha przyjmuje tu postać ogólną, bez

2 Zob. J. Zajadło, Formuła Radbrucha. Filozofia prawa na granicy pozytywizmu prawniczego i prawa natury, Gdańsk 2001, s. 231-270. W literaturze przedmiotu zwraca się uwagę, że wobec upozytywnienia zawartości materialnej formuły Radbrucha zakres jej możliwego bezpośredniego zastosowania praktycznego jest ograniczany. Kwestia ta jednak pozostaje sporna; zob. R. Dreier, S.L. Paulson, Wprowadzenie do filozofii prawa Radbrucha, [w:] G. Radbruch, Filozofia prawa, przeł. E. Nowak, Warszawa 2009, s. CVII; M. Lubertowicz, Lex iniustissima non est lex. Formuta Gustava Radbrucha jako alternatywa dla międzynarodowego systemu ochrony praw człowieka, „Wrocławskie Studia Erazmiańskie”, z. 4. Prawa człowieka - idea, instytucje, krytyka, red. M. Sadowski, P. Szymaniec, 2010.

${ }^{3}$ W sprawie wyszczególnienia różnych kontekstów aktualności i znaczenia formuły zob. J. Zajadło, Formuła Radbrucha - geneza, treść, zastosowanie, „Państwo i Prawo” 2000, z. 6, s. 27.

4 J. Zajadło, Formuła Radbrucha. Filozofia..., s. 70 oraz recenzja tej pracy, napisana przez Lecha Morawskiego („Państwo i Prawo” 2002, z. 2, s. 98). Obydwaj teoretycy podkreślają wykraczanie znaczenia formuły Radbrucha poza kontekst systemów totalitarnych.

5 Zob. np. R. Dreier, S.L. Paulson, op. cit., s. CVIII.

${ }^{6}$ H.L.A. Hart, Pozytywizm i oddzielenie prawa od moralności, [w:] idem, Eseje z filozofii prawa, przeł. J. Woleński, Warszawa 2001, s. 72-77. Pewne mniej bezpośrednie nawiązania do Radbrucha znajdują się też w głównym dziele brytyjskiego filozofa — zob. idem, Pojęcie..., s. 269-285. 
detalicznego ważenia słów niemieckiego klasyka, wskazywania analizowanych stron oraz z pominięciem prac przedwojennych. Hart przyjmuje przy tym popularną w czasie pisania jego artykułu tezę o radykalnej przemianie autora Pięciu minut filozofii prawa z przedwojennego pozytywisty na powojennego zwolennika doktryny prawa natury ${ }^{7}$.

Wydaje się, że można wskazać przynajmniej trzy powody, dla których dokonana przez Harta krytyka uzyskała status „kanonicznej” i stała się podstawowym punktem odniesienia przy analizowaniu stanowiska Radbrucha. Po pierwsze, jest to efekt niezwykłej pozycji brytyjskiego mysliciela w światowej nauce. Pojęcie prawa zapoczątkowało bardzo dynamiczny rozwój anglosaskiej, analitycznie zorientowanej filozofii prawa, dostarczając jej mistrzowsko skrojonej siatki konstrukcji teoretycznych, które były następnie dyskutowane, uzupełniane i przekształcane. Po drugie - co ściśle wiąże się z poprzednim — dokonana przez Harta krytyka Radbrucha była punktem zapalnym słynnej i również mającej znaczenie formacyjne dla zachodniego prawoznawstwa debaty między brytyjskim filozofem a Lonem Luvoisem Fullerem ${ }^{8}$. Polemika ta miała jednak swoją wewnętrzną dynamikę $\mathrm{i}$ — jak trafnie wskazuje się w literaturze ${ }^{9}$ — obaj dyskutanci przyjmowali mocno uproszczony obraz filozofii Radbrucha, traktując ją raczej jako wygodny punkt odniesienia dla wyłożenia własnych konstrukcji niż jako samoistny przedmiot badawczy. Po trzecie wreszcie, taki stan rzeczy można też połączyć z okolicznością, na którą w innym kontekście wskazuje Jerzy Zajadło. Gdański filozof prawa odnotowuje mianowicie, że dokładne, drobiazgowe analizy formuły Radbrucha, poddające ją szczegółowemu badaniu, miały miejsce dopiero na przełomie lat osiemdziesiątych i dziewięćdziesiątych minionego wieku ${ }^{10}$. Przez długi czas uwagi zgłoszone przez Harta funkcjonowały zatem - przynajmniej w anglosaskiej filozofii prawa - w roli jednej z nielicznych krytycznych analiz formuły Radbrucha.

Jak wspomniałem, w niniejszym tekście postaram się przyjrzeć zarzutom formułowanym przez Harta, próbując zarazem pokazać, że między myśleniem

7 Na marginesie warto odnotować, że nieco myląca wydaje się informacja podana przez Ewę Nowak, jakoby Hart miał „upierać się” w przyjmowaniu, że w filozofii Radbrucha doszło do rewolucyjnej przemiany (Zob. eadem, Stowo od tlumacza, [w:] G. Radbruch, Filozofia..., s. LXXIX). $\mathrm{O}$ żadnym uporze mowy tu być raczej nie powinno z tego choćby powodu, że Hart się tą kwestią szczegółowo nie zajmował. Nie odwoływał się on do przedwojennych pism niemieckiego filozofa i nie analizował ich w swoich pracach. Tam zaś, gdzie autor Pojęcia prawa wspomina o zmianie stanowiska przez Radbrucha, twierdzenie o owej rzekomej konwersji pojawia się nie w charakterze będącej przedmiotem argumentacji tezy, lecz w roli krążącego w obiegu naukowym stwierdzenia, które brytyjski myśliciel przyjmuje za prawdziwe i które powinno być — jego zdaniem — podane do wiadomości w anglojęzycznych przekładach jego pism (zob. idem, Pozytywizm i oddzielenie..., s. 72, 74).

${ }^{8}$ Rzecz została szczegółowo zrelacjonowana w T. Snarski, Debata Hart-Fuller i jej znaczenie dla filozofii prawa, Gdańsk 2018.

9 Zob. J. Zajadło, Formuła Radbrucha. Filozofia..., s. 203-205; idem, Radbruch, Sopot 2016, s. 196-197 (oraz podana tam literatura).

10 J. Zajadło, Formuła Radbrucha. Filozofia..., s. 273.

Studia nad Autorytaryzmem i Totalitaryzmem 42, nr 2, 2020

(C) for this edition by CNS 
tych dwóch wielkich postaci dwudziestowiecznej filozofii prawa nie musi być aż takiej przepaści, jak można by się spodziewać oraz jak przyjmował sam Hart. Tak nakreślone zadanie badawcze zrealizowane będzie w kilku krokach. Na początku wypadnie powiedzieć parę słów o podstawie do rekonstrukcji formuły Radbrucha. Następnie odtworzę treść tej formuły, sygnalizując przy tym kilka wątpliwości interpretacyjnych. W dalszej kolejności zrekonstruuję zarzuty podnoszone wobec niej przez Harta, proponując sprowadzenie ich do dwóch podstawowych, które nazwę argumentem pojęciowym i argumentem empirycznym. W kolejnych częściach tekstu podejmę dyskusję z tymi argumentami oraz wskażę pewną możliwość przekonfigurowania omawianego sporu. Całość zamknie krótka, podsumowująca uwaga końcowa.

\section{Podstawa do rekonstrukcji formuły Radbrucha}

To, co określa się mianem „formuły Radbrucha”, jest dosyć złożoną strukturą filozoficzno-prawną, rekonstruowaną przez komentatorów na podstawie pism niemieckiego klasyka. Jak zwraca się uwagę w literaturze, formuła budzi spory nie tylko co do oceny jej zasadności oraz konsekwencji praktycznego zastosowania, lecz również co do sposobu interpretacji składających się na nią pojęć ${ }^{11}$. Co ciekawe, nawet te kwestie, które wydają się już dobrze przedyskutowane i wyjaśnione - jak na przykład relacja między treścią formuły a zawartością przedwojennej filozofii Radbrucha - powracają, wywołują pytania i angażują kolejnych dyskutantów.

Podstawę rekonstrukcji i interpretacji formuły Radbrucha proponuję podzielić na trzy części. Pierwsza z nich to opublikowany w 1946 roku artykuł tegoż, zatytułowany Ustawowe bezprawie i ponadustawowe prawo ${ }^{12}$, o której to pracy nie bez powodu napisano, że „okazał on się praktycznie najbardziej wpływowym tekstem, jaki wydała dwudziestowieczna filozofia prawa"13. Badacze są zgodni, że to właśnie w tym miejscu formuła Radbrucha znalazła swoją najbardziej dopracowaną i względnie najklarowniej wyłożoną postać. Na drugą część składają się trzy inne powojenne pisma niemieckiego filozofia, to jest: słynne, króciutkie Pięć minut filozofii prawa ${ }^{14}$ (1945), znacznie mniej znany artykuł Ustawa i prawo ${ }^{15}$ (1947) oraz powstały w roku 1947, ale udostępniony szerszej publiczności dopiero w roku 1999, niedokończony szkic posłowia do planowanego

11 Ibidem, s. 105, 271.

12 G. Radbruch, Ustawowe bezprawie i ponadustawowe prawo (dodatek 3), [w:] G. Radbruch, Filozofia ..., s. 244-254.

13 R. Dreier, S.L. Paulson, op. cit., s. CVII.

14 G. Radbruch, Pięć minut filozofii prawa (dodatek 2), [w:] G. Radbruch, Filozofia..., s. $241-243$.

15 G. Radbruch, Ustawa i prawo, przeł. J. Zajadło, [w:] J. Zajadło, Radbruch ..., s. 31-37. 
wznowienia Filozofii prawa ${ }^{16}$. Trzeci wreszcie obszar dorobku Radbrucha, który może służyć nie tyle już do samej rekonstrukcji interesującej nas formuły, ile do jej interpretacji, to jego przedwojenne prace, zwłaszcza zaś młodzieńczy Wstęp do prawoznawstwa $(1910)^{17}$ oraz znacznie późniejsza Filozofia prawa $(1932)^{18}$. Decyzja o ich uwzględnieniu bądź odrzuceniu przy analizie formuły jest w dużym stopniu pochodną stanowiska w kontrowersji co do relacji między powojenną perspektywą filozoficzno-prawną Radbrucha a jego poglądami przedwojennymi czy też — ujmując rzecz ściślej — zapatrywaniami wyrażanymi przed 1933 rokiem. Jakkolwiek bowiem nie ma sporu co do tego, że dochodzi tu do pewnych przemieszczeń, to nie ma już zgody co do oceny ich zakresu i znaczenia. Jedni mówią o spektakularnej rewolucji, inni dopatrują się ewolucji, a jeszcze kolejni badacze twierdzą, że mamy raczej do czynienia z wynikającą ze zmiany kontekstu społeczno-politycznego różnicą w rozłożeniu akcentów przy zachowaniu zasadniczej ciągłości i konsekwencji wcześniejszego sposobu myślenia ${ }^{19}$.

Aby uniknąć czynienia $z$ tego zagadnienia tematu, ale zarazem usprawiedliwić się z włączenia przedwojennego dorobku Radbrucha do analizy jego słynnej formuły, krótko odnotuję trzy argumenty na rzecz twierdzenia o istnieniu zasadniczej ciągłości myśli niemieckiego klasyka, co oczywiście nie przeczy istnieniu pewnych przekształceń. Po pierwsze więc, dokładnie tak stawia sprawę sam Radbruch w udostępnionym stosunkowo niedawno, wspomnianym już szkicu posłowia do planowanego powojennego wydania Filozofii prawa. Deklaracja ta nie musi być traktowana jako argument rozstrzygający, ale też nie należy jej lekceważyć. Czytamy tam mianowicie o „kontynuacji, a także przebudowie”20 wypracowanych wcześniej struktur teoretycznych. Radbruch akcentuje przy tym cztery czynniki, które miały decydujące znaczenie dla rozwoju i przekształceń przyjmowanych przez siebie rozstrzygnięć. Oprócz najważniejszych i najbardziej oczywistych, czyli doświadczenia dyktatury narodowego socjalizmu oraz „upadku i okupacji Niemiec"21, wskazuje też dwa inne. Pierwszym z nich jest to, co określa mianem „powrotu chrześcijaństwa”, a przez co rozumie odzyskanie

16 G. Radbruch, Projekt postowia do „Filozofii prawa”, (dodatek 1), [w:] G. Radbruch, Filozofia..., s. 223-240. Powodem nieudostępniania przez długi czas tego fragmentu spuścizny Radbrucha był właśnie, wspomniany już szkicowy, niedokończony charakter tekstu (zob. uwagę od wydawcy) - G. Radbruch, Projekt..., s. 223-224.

17 G. Radbruch, Wstęp do prawoznawstwa, przeł. C. Znamierowski, Warszawa 1924.

18 G. Radbruch, Filozofia... Praca ta została wydana w 1932 roku, ale była w dużym stopniu oparta na Zarysie filozofii prawa, którą to książkę Radbruch opublikował już w roku 1914. Bardziej szczegółowe informacje o twórczości naukowej oraz drodze życiowej Radbrucha zob. J. Zajadło, Radbruch..., s. 61-199.

19 Zob. J. Zajadło, Formuła Radbrucha. Filozofia..., s. 275-283; T. Chauvin, Sprawiedliwość: między celowościa a bezpieczeństwem prawnym. Ewolucja poglądów Gustava Radbrucha, „Studia Iuridica” 37, 1999; D. Bogacz, Formuła i filozofia prawa Gustava Radbrucha, „Ruch Prawniczy, Ekonomiczny i Socjologiczny" 2002, z. 3.

20 G. Radbruch, Projekt..., s. 224.

21 Ibidem. 
wiary $\mathrm{w}$ znaczenie i rolę religii chrześcijańskiej, wynikające z zasadniczo krytycznej postawy Kościoła wobec narodowego socjalizmu ${ }^{22}$. Drugim natomiast z dodatkowych czynników jest rozwój i powodzenie filozofii egzystencji, a więc perspektywy, która dostarcza innego rodzaju wrażliwości teoretycznej niż wcześniejsze nurty filozoficzne ${ }^{23}$.

Oprócz argumentu z deklaracji składanej przez samego Radbrucha przywołajmy jeszcze dwie dalsze racje przemawiające za odrzuceniem tezy o jakimś radykalnym zerwaniu przez niego ze swoim dorobkiem wypracowanym przed dojściem Hitlera do władzy. Otóż lektura przedwojennych pism autora Pięciu minut filozofii prawa nie pozostawia wątpliwości, że formuła Radbrucha bardzo dobrze wpisuje się w koncepcję trzech antynomicznych składników idei prawa, to jest sprawiedliwości, bezpieczeństwa prawnego i celowości. Sama formuła jawi się w tym kontekście jako coś, co jest rozstrzygnięciem dokonanym w ramach tej koncepcji, a nie jako coś, co ma ją zastąpić.

I ostatni argument — trzeba jasno powiedzieć, że mimo podnoszonych w literaturze wątpliwości co do zachowania ciągłości w teorii Radbrucha, większość badaczy przychyla się dziś do stwierdzenia, że nie ma podstaw, by mówić tu o jakimś zerwaniu.

\section{Elementy składowe formuły}

Jakkolwiek sprawa nie jest bezsporna i między poszczególnymi rekonstrukcjami obecnymi w literaturze widoczne są całkiem spore różnice ${ }^{24}$, to najczęściej przyjmuje się, że na formułę Radbrucha składają się trzy komplementarne względem siebie twierdzenia. Wedle pierwszego z nich, nazwanego przez komentatorów „formułą uciążliwości”, jeśli prawo jest niesprawiedliwe „w stopniu nieznośnym”, to należy odmówić mu obowiązywania. Wedle stwierdzenia drugiego, określanego mianem „formuły lekceważenia” (lub inaczej „tezy odmowy”), jeśli prawodawca świadomie nie dąży do sprawiedliwości i lekceważy będącą jej istotą równość, to nie tyle mamy już do czynienia z prawem niesprawiedliwym, ile

22 Ibidem, s. 234-237.

23 Ibidem, s. 234, 238-240.

24 Por. R. Alexy, W obronie niepozytywistycznej koncepcji prawa, przeł. L. Morawski, „Państwo i Prawo" 1993, z. 11-12, s. 36; J. Zajadło, Formuła Radbrucha-geneza..., s. 27-31; idem, Formuła Radbrucha. Filozofia..., s. 105-136; H.P. Graver, Judges Against Justice. On Judges When the Rule of Law is Under Attack, Berlin-Heidelberg 2015, s. 143-144; M. Piechowiak, Sprawiedliwe prawo - niesprawiedliwe wyroki. Uwagi na marginesie Arthura Kaufmanna koncepcji prawa do sprzeciwu wobec władzy, [w:] O prawach człowieka. Księga jubileuszowa Profesora Romana Wieruszewskiego, red. G. Baranowska et al., Warszawa 2017, s. 110-111; B. Bix, Robert Alexy, Radbruch's formula, and the nature of legal theory, „Rechtstheorie” 2006, z. 37, s. 140-142; J. Oniszczuk, Filozofia i teoria prawa, Warszawa 2012, s. 284; M. Zirk-Sadowski, Wprowadzenie do filozofii prawa, Kraków 2000, s. 172-173. 
z czymś, co prawem w ogóle nie jest. Trzecie wreszcie twierdzenie - funkcjonujące pod szyldem „tezy o bezbronności” i nie zawsze traktowane jako część samej formuły - sprowadza się do uznania, że pozytywizm prawniczy uniemożliwił prawnikom obronienie niemieckiego systemu prawnego przed hitlerowską barbaryzacją i uczynił ich bezwolnym narzędziem nazistowskiej władzy.

Dwie pierwsze formuły pozwalają wyróżnić trzy poziomy niesprawiedliwości prawa. Przy poziomie pierwszym, najniższym, niesprawiedliwe prawo wciąż obowiązuje. Przy poziomie drugim, kiedy niesprawiedliwość osiąga „stopień nieznośny", prawo przestaje obowiązywać. Przy poziomie trzecim, kiedy prawodawca intencjonalnie lekceważy wymogi sprawiedliwości, jego wytwór nie tylko traci walor obowiązywania, ale w ogóle przestaje być rozpoznawany jako prawo. Kluczowy dla ustalenia treści dwóch pierwszych formuł jest następujący fragment artykułu Radbrucha:

Konflikt między sprawiedliwością a bezpieczeństwem prawnym dałby się rozstrzygnąć $\mathrm{w}$ ten sposób, że prawo stanowione, gwarantowane przez ustawy i władzę, zachowałoby prymat nawet mimo niecelowości i niesprawiedliwej treści — z wyjątkiem sytuacji, kiedy ustawa w stopniu tak nieznośnym przeczy sprawiedliwości, że ta ostatnia musi ostatecznie przeważyć nad „prawem niesprawiedliwym”. Nie da się ostrzej odgraniczyć przypadków ustawowego bezprawia od praw, które obowiązują mimo niesprawiedliwej treści; da się jednak przeprowadzić ścisłą granicę tam, gdzie nikt nie dąży do sprawiedliwości i gdzie ustawodawstwo świadomie ignoruje równość, która jest jądrem sprawiedliwości; wówczas bowiem ustawa nie jest li tylko „prawem niesprawiedliwym”, lecz traci w ogóle rangę i charakter prawa ${ }^{25}$.

Tytułem komentarza cztery uwagi. Po pierwsze, trzeba podkreślić, że zgodnie z formułą Radbrucha - co jest w przytoczonych słowach stwierdzone explicite — prawo niesprawiedliwe lub niecelowe pozostaje, co do zasady, obowiązującym prawem mimo takich swoich właściwości. Formuły uciążliwości i lekceważenia nie wyznaczają zatem jakiegoś zwykłego trybu działania, przewidzianego na okoliczność, w której refleksja nad sprawiedliwością obowiązującego porządku prawnego wypadnie dla niego wątpliwie czy nawet niepomyślnie. Formuła Radbrucha jest więc nie tyle zanegowaniem jego wcześniejszego sposobu myślenia o prawie, ile wprowadzeniem przewidzianej na ekstremalnie wyjątkowe okoliczności „możliwości awaryjnej”, dopełniającej teoretyczne rozwiązania wypracowane w Filozofii prawa ${ }^{26}$. W artykule Ustawa i prawo czytamy:

Pozytywizm miał jednak swoje dobre strony i nie można pomijać go milczeniem. W zasadzie musi zachować aktualność teza, że ustawa powinna być uznawana za obowiązujące prawo bez względu na swoją treść. Państwo prawa i bezpieczeństwo prawne wymagają zasadniczego związania ustawą. Tylko w pojedynczych, wyjątkowych przypadkach można od niego odstą-

25 G. Radbruch, Ustawowe..., s. 250.

26 Zob. H. Leawoods, Gustav Radbruch: An extraordinary legal philosopher, „Journal of Law and Policy" 2000, z. 2. 
pić, tylko w przypadkach, które przeżyliśmy w okresie nazizmu i których, miejmy nadzieję, więcej nie będziemy przeżywać ${ }^{27}$.

Marek Piechowiak mówi w tym kontekście o „ciemnej stronie formuły Radbrucha" 28 . Odpowiedzią na to ograniczenie rozwiązania danego przez autora Pięciu minut filozofii prawa jest propozycja jego uzupełnienia, zgłoszona przez najbardziej znanego z jego uczniów - Arthura Kaufmanna. Ten czołowy przedstawiciel współczesnej hermeneutyki prawniczej wypracował własną koncepcję, którą nazywa „prawem do sprzeciwu w drobnej monecie"29. Najogólniej rzecz ujmując, wpisujące się $\mathrm{w}$ tę konstrukcję działania polegają na sprzeciwianiu się niesprawiedliwemu prawodawcy przez różne zachowania, które otwarcie manifestują krytyczną ocenę obywatelską. Zachowania te jednak - co odróżnia model Kaufmanna od związanego głównie z tradycją amerykańską modelu obywatelskiego nieposłuszeństwa - nie naruszają obowiązującego porządku prawnego. Interesująca jest również wskazana przez Piechowiaka - w nawiązaniu do sposobu myślenia Kaufmanna - propozycja modyfikacji formuły Radbrucha, polegająca na - mówiąc ogólnie - dokonaniu przesunięcia interwencji z poziomu walidacyjnego na poziom aplikacyjny. Chodzi zatem o rodzaj słusznościowej korekty dokonywanej na etapie stosowania aktów prawnych, które powszechnie nie wydają się niesprawiedliwe w stopniu nieznośnym, ale w konkretnym wypadku ich zastosowanie miałoby takie skutki ${ }^{30}$.

Po drugie, wydaje się pod pewnym względem paradoksalne, że w orzecznictwie znalazła szersze zastosowanie pierwsza, a nie druga $\mathrm{z}$ formuł. Zauważmy bowiem - co widać w przytoczonym cytacie — że sam Radbruch sygnalizuje, iż trudne może być wskazanie granicy niesprawiedliwości potrzebnej do zastosowania pierwszej formuły. Wygląda na to, że dlatego właśnie podaje formułę drugą, w której - jak pisze explicite — przebieg granicy nie powinien budzić wątpliwości. Tymczasem praktyka orzecznicza przyjęła — odwrotnie niż Radbruch — że mniej kontrowersyjnie jest uznać, iż jakieś regulacje prawne naruszają sprawiedliwość w stopniu nieznośnym, niż udowodnić prawodawcy celowe lekceważenie sprawiedliwości, to jest wykazać jego złą wolę i intencjonalne ignorowanie wymogów równości ${ }^{31}$. Taki obrót sprawy jest tym bardziej zaskakujący, że sam autor Pięciu minut filozofii prawa sporo uwagi poświęca ukazaniu nieistnienia podstaw do wątpliwości co do złej woli Hitlera, czyli celowego lekceważenia przez niego najbardziej elementarnych względów sprawiedliwości ${ }^{32}$. Radbruch podkreśla, że taka właśnie, niepozostawiająca złudzeń co do intencji prawodawcy, sytuacja zaistniała w III Rzeszy, gdzie prawo „nie było już nawet prawem

\footnotetext{
27 G. Radbruch, Ustawa..., s. 36.

28 M. Piechowiak, op. cit., s. 112.

29 Ibidem, s. 112-117.

30 Ibidem, s. 122-127.

31 Zob. R. Dreier, S.L. Paulson, op. cit., s. CVII.

32 Zob. ibidem, s. CVII, przyp. 42.
} 
niesprawiedliwym, lecz przestało być w ogóle prawem"33. Czytamy w tej sprawie:

\begin{abstract}
Narodowy socjalizm podważył absolutnie wszystkie zasady prawne i ujawnił wszelkie możliwe postacie, jakie tylko przyjąć może bezprawie. Państwo prawne, które zastał jako faktyczny stan rzeczy, zamienił w „państwo bezprawia” w najpełniejszym tego słowa znaczeniu. Najgroźniejszą odmianą bezprawia jest zaś takie, które przebiera się w insygnia prawa: nazywamy je „bezprawiem ustawowym”34.
\end{abstract}

Po trzecie zauważmy, że teoretycznie interesująca jest różnica w zakresie tego, jakie dokładnie konsekwencje należy łączyć z rozróżnieniem między postacią niesprawiedliwości związaną z formułą uciążliwości a jej typem kwalifikowanym, łączącym się z formułą lekceważenia ${ }^{35}$. Czym bowiem miałoby się różnić prawo, które nie obowiązuje, od czegoś, co prawem w ogóle nie jest? $\mathrm{W}$ jakim sensie nieobowiązujące prawo - a więc derogowane $\mathrm{z}$ mocą wsteczną na podstawie pierwszej formuły — ciągle jeszcze jest — wobec niepodpadania pod drugą formułę - prawem? Mówiąc inaczej jeszcze: na czym dokładnie polega różnica między odmówieniem jakimś regulacjom obowiązywania a odmówieniem im bytu prawnego? W literaturze wskazuje się, że formuła uciążliwości należy do teorii obowiązywania prawa, formuła lekceważenia zaś — do teorii pojęcia prawa ${ }^{36}$. Wyjaśnienie to staje się jednak problematyczne, jeśli przyjąć takie koncepcje prawa, które włączają element obowiązywania do samego pojęcia prawa $^{37}$. Dla przykładu Robert Alexy w kontekście wskazanego przez Radbrucha kryterium przekroczenia nieznośnego stopnia niesprawiedliwości przez normy prawne mówi explicite o odmowie uznania charakteru prawnego takich norm, a nie o uchyleniu ich obowiązywania z mocą wsteczną ${ }^{38}$.

Problem rozwiązywałby się natomiast przy przyjęciu takiej interpretacji, wedle której przy formule uciążliwości chodzi nie o odmówienie obowiązywania, lecz - na podobieństwo sygnalizowanej modyfikacji proponowanej przez Piechowiaka — samego zastosowania. Jakkolwiek na gruncie przytoczonych wcześniej słów z Ustawowego bezprawia i ponadustawowego prawa wydaje się to dopuszczalne, to jednak przyjęte rekonstrukcje mówią tu o odmówieniu obowiązywania, a nie samego zastosowania, dlatego Piechowiak nieprzypadkowo określa swoją propozycję jako modyfikację. Trzeba też przyznać, że odczytanie, w którym mowa o odmówieniu obowiązywania, a nie samego zastosowania, pozwala pogodzić sformułowanie obecne we wskazanym dopiero co artykule

33 G. Radbruch, Ustawowe..., s. 251.

34 G. Radbruch, Projekt..., s. 225.

35 Por. J. Zajadło, Formuła Radbrucha. Filozofia..., s. 109-112.

36 R. Dreier, S.L. Paulson, op. cit., s. CVIII.

37 Krytyczną analizę takich konstrukcji możemy znaleźć w T. Gizbert-Studnicki, A. Grabowski, Kilka uwag o niepozytywistycznej koncepcji prawa, [w:] Prawo a wartości. Księga Jubileuszowa Profesora Józefa Nowackiego, red. I. Bogucka, Z. Tobor, Kraków 2003.

38 R. Alexy, op. cit., s. 36, 42, 44. 
Radbrucha z Pięcioma minutami filozofii prawa, gdzie wyraźnie jest już mowa o odmowie obowiązywania jako owym łagodniejszym wariancie ${ }^{39}$. Ponieważ jednak Ustawowe bezprawie $i$ ponadustawowe prawo jest tekstem późniejszym i przyjmuje się, że formuła przybrała tam bardziej dopracowaną postać, to sprzeczność interpretacji z brzmieniem wcześniejszego tekstu nie wydaje się argumentem rozstrzygającym. Istnieje jednak inny jeszcze powód odrzucenia takiej interpretacji - wydaje się mianowicie, że pierwsza formuła byłaby wtedy jeszcze bardziej problematyczna z punktu widzenia możliwości aplikacji w praktyce orzeczniczej, a dokładnie w tym jej obszarze, który dotyczy odpowiedzialności karnoprawnej. Jakkolwiek bowiem tak interpretowana formuła mogłaby dalej być rozważana jako argument za wyjątkowym odstąpieniem od stosowania niektórych przepisów, to znacznie trudniej byłoby wtedy powoływać się na nią w charakterze argumentu za pociąganiem do odpowiedzialności za to, co określa się jako przestępstwa sterowane przez państwo.

Czytając słowa samego Radbrucha, można przyjąć w tej sprawie jeden jeszcze trop. Trudno mianowicie nie wziąć pod uwagę możliwości, że intencje myśliciela były znacznie prostsze, niż przyjmuje się w rekonstrukcjach wyodrębniających formułę uciążliwości i odmowy. Można bowiem rozważyć taką interpretację słów niemieckiego klasyka, wedle której prawo rażąco niesprawiedliwe nie obowiązuje, ewentualne zaś i możliwe wątpliwości co do stopnia nasycenia niesprawiedliwością wystarczającego do odrzucenia prawa muszą być przecięte najpóźniej wtedy, gdy prawodawca świadomie i celowo ignoruje względy sprawiedliwości, to jest porzuca w ogóle ideę prawa, tworząc swoiste antyprawo. Zobaczmy, że w takim ujęciu nie ma już dwóch dopełniających się formuł składowych, lecz jest jedna, a to, co wcześniej było interpretowane jako różnica między formułą nieznośności a formułą odmowy, sprowadzone jest tu do progu, po którego przekroczeniu nie należy już mieć wątpliwości co do zasadności zastosowania formuly.

$\mathrm{Z}$ jednej strony taka interpretacja wyłamuje się $\mathrm{z}$ ustabilizowanej $\mathrm{w}$ tym zakresie tradycji rekonstruowania formuły ${ }^{40}$ (a więc zachodzi spore ryzyko, że z jakichś powodów jest jednak błędna), z drugiej zaś strony można wskazać klika dobrych — jak sądzę — racji, dla których nie należy zbyt szybko porzucać tego tropu. Po pierwsze, nie widać w słowach samego Radbrucha niczego, co by podważało taką interpretację. Po drugie, wydaje się ona dobrze pasować do trafnie wydobytego przez Jerzego Zajadłę emocjonalnego i osobistego charakteru

39 Zob. G. Radbruch, Pięć minut..., s. 243. Czytamy tam: „Prawnicy i obywatele muszą sobie w swojej świadomości głęboko zakonotować, że możliwe [wyr. oryg.] są prawa przechodzące wszelką miarę niesprawiedliwości i szkodliwości społecznej, prawa, którym należy odmówić nie tylko mocy obowiązywania, lecz także wszelkiego charakteru prawnego".

40 J. Zajadło pisze w tym kontekście o istnieniu utrwalonego „metodologicznego standardu” — zob. idem, Formula Radbrucha. Filozofia..., s. 130. 
powojennych wypowiedzi niemieckiego filozofa ${ }^{41}$. Podstawową troską Radbrucha nie były subtelne, bliskie scholastyki dystynkcje teoretyczne, lecz wynikające z palącej potrzeby praktycznej wskazanie, że istnieje takie natężenia zła, które nie może już budzić żadnych rozsądnych wątpliwości co do swojego charakteru i które musi być rozpoznawalne w myśleniu prawniczym. Po trzecie, warto zauważyć, że interpretacja przyjmująca, iż celem Radbrucha nie było ustanowienie dwóch dopełniających się formuł, lecz jednej, pojawia się też w literaturze, choć — trzeba przyznać - jest to stanowisko rzadkie ${ }^{42}$.

I jeszcze ostatni z zapowiedzianych komentarzy. Formuła Radbrucha jest pewnym przeszeregowaniem $w$ ramach przyjętej przez niego wcześniej koncepcji trzech składowych idei prawa ${ }^{43}$. Przypomnijmy, że są nimi: bezpieczeństwo, celowość i sprawiedliwość. Niemiecki autor podkreśla, że elementy te łączą się nie na zasadzie harmonii, lecz rywalizacji i walki, w kontekście której czytamy o możliwości różnych rozstrzygnięć w „dialektycznej rozgrywce”44. Prawo jako całość jest więc ideą antynomiczną. Porządkując tę problematykę, Radbruch pisze, że myślenie w duchu prawnonaturalnym daje pierwszeństwo sprawiedliwości, pozytywizm prawniczy eksponuje wartość bezpieczeństwa prawnego, a zarządzane w duchu autorytarnym państwo policyjne - dobru powszechnemu ${ }^{45}$. Antynomiczność idei prawa przejawia się jednak nie tylko w napięciach między trzema jej elementami, lecz również w istnieniu różnych konkurencyjnych sposobów rozumienia sprawiedliwości ${ }^{46}$ oraz celowości prawa ${ }^{47}$.

W zakresie tej ostatniej Radbruch zderza ujęcie indywidualistyczne z supraindywidualistycznym ${ }^{48}$ (która to opozycja mocno przypomina późniejszy spór liberalizmu z komunitaryzmem), a w Filozofii prawa dołącza jeszcze do tego model trzeci - transindywidualistyczny ${ }^{49}$. Poszczególne modele celowości prawa są $\mathrm{w}$ istocie różnymi koncepcjami państwa, rozstrzygnięcie zaś między nimi nie

41 Ibidem, s. 105.

42 Takie stanowisko przedstawia Thomas Mertens - zob. idem, Radbruch and Hart on the grudge informer: A reconsideration, „Ratio Juirs” 15, 2002, z. 2, s. 190-192. Z kolei Brian Bix twierdzi, że choć z wypowiedzi Radbrucha jasno wynika, iż druga formuła miała być tylko korektą pierwszej, to w efekcie wyszły dwie całkiem różne formuły — zob. idem, Robert Alexy..., s. 140.

43 G. Radbruch, O celu prawa, przeł. K. Matuszewski, „Ruch Prawniczy, Ekonomiczny i Socjologiczny" 1937, z. 3; idem, Filozofia..., s. 79-84.

44 G. Radbruch, $O$ celu..., s. 336.

45 Zob. ibidem.

${ }^{46}$ Komentatorzy Radbrucha zaznaczają czasem, że jego pisma nie są wolne od niejasności i pewnych napięć (zob. np. P. Łącki, Radbruch dzisiaj. Kilka uwag na marginesie nowego przekładu „Filozofii prawa”, „Ruch Prawniczy, Ekonomiczny i Socjologiczny” 2011, z. 3, s. 283; M. Piechowiak, op. cit. s. 108). Wydaje się, że sposób, w jaki Radbruch ujmował sprawiedliwość w pierwszym okresie swojej twórczości, jest jednym z takich elementów, w których trudno uzgodnić z sobą wszystkie wypowiedzi z tego czasu. Są bowiem i takie fragmenty jego pism, w których zdaje się przyjmować, że sprawiedliwość nie jest czymś relatywnym — por. G. Radbruch, Filozofia..., s. 4, 80, 89).

47 G. Radbruch, Projekt..., s. 239.

48 G. Radbruch, Wstęp..., s. 16-21.

49 G. Radbruch, Filozofia..., s. 58-67. 
jest sprawą jakiegoś naukowo ugruntowanego wglądu teoretycznego, lecz kwestią światopoglądową, która na poziomie społecznym rozstrzygana jest $\mathrm{w}$ drodze rywalizacji zabiegających o władzę partii politycznych ${ }^{50}$. Nie ma tu więc lepszej metody niż zawierzenie procedurze demokratycznej, pozwalającej proponować i wybierać programy społeczno-polityczne. W związku jednak z sygnalizowaną treściową otwartością sprawiedliwości i celowości jako elementów składowych idei prawa Radbruch w okresie przed 1933 rokiem mocno podkreślał priorytetowy charakter - przynajmniej dla prawników — trzeciego ze składników, to jest bezpieczeństwa prawnego ${ }^{51}$. Postrzegane ono było jako ten składnik idei prawa, który ma zapewnić swoisty balans całości przez rekompensowanie wysokiego stopnia blankietowości pozostałych dwóch elementów.

Zwróćmy teraz uwagę na to, co wydarzyło się z punktu widzenia omawianej koncepcji w trakcie istnienia III Rzeszy. Otóż wbrew pozorom ostatecznie doszło tam nie tyle do marginalizacji sprawiedliwości na rzecz ekspansji celowości i pewności prawa, ile do rozkładu wszystkich tych trzech elementów. Trzeba bowiem — za Radbruchem — podkreślić, że stopień naruszenia sprawiedliwości przez władzę Hitlera był tak duży, iż pociągnął za sobą zniszczenie bezpieczeństwa i celowości prawa.

Warto przy tym przypomnieć, że bezpieczeństwo prawne ma wedle Radbrucha trzy aspekty: bezpieczeństwo przez prawo (na przykład zabezpieczenie takich wartości jak życie czy majątek), bezpieczeństwo prawa (to jest jego poznawalności, względnej stabilności, egzekwowalności) oraz umożliwiające racjonalne planowanie bezpieczeństwo uprawnienia ${ }^{52}$. Mechanizmy społeczno-polityczne uruchomione w III Rzeszy niszczyły tak ujmowane bezpieczeństwa prawne, co przejawiało się między innymi w takich zjawiskach, jak: „zniesienie wszystkich niemal ograniczeń konstytucyjnych dla działalności rządu i ustawodawcy"53, przyznanie nieograniczonych kompetencji policji, przyzwolenie dla nieprzejrzystego sposobu działania wymiaru sprawiedliwości czy też uzyskanie przez władze państwowe prawa do kwestionowania prawomocnych wyroków sądowych ${ }^{54}$. Radbruch zwraca również uwagę na zdegenerowanie się procesu prawodawczego w państwie Hitlera:

Brak bezpieczeństwa prawnego pogłębił się gwałtownie, odkąd można było zmieniać prawo w dowolnej chwili i bez żadnych ograniczeń. Pieczę nad ustawodawczą klamką sprawował teraz niepodzielnie wódz. Nic już nie stało na przeszkodzie temu, aby pomysły świtające w jego głowie natychmiast trafiały do publicznego dziennika ustaw III Rzeszy: żadne czytanie projektu ustawy, obrady parlamentarne ani głosowania. Trafiały one wprost do drukarni, we dnie

50 G. Radbruch, Wstep..., s. 19-31. Zob. też M. Szyszkowska, Europejska filozofia prawa, Warszawa 1995, s. 102-104.

51 G. Radbruch, Wstęp..., s. 31-35; idem, Filozofia..., s. 91-94.

52 G. Radbruch, $O$ celu..., s. 330-331.

53 G. Radbruch, Projekt..., s. 225.

54 Ibidem, s. 225-229. 
i w nocy obsługującej kancelarię Rzeszy. Ustawiczne mnożenie ustaw i nowelizacji zdeformowało i ostatecznie zrujnowało niemieckie prawo ${ }^{55}$.

Wobec sprowadzania celu prawa do ,pierwszego lepszego kaprysu i wymysłu władcy" ${ }^{" 56}$ zniszczony został także trzeci składnik idei prawa, to jest jego celowość.

Ujawnia się tu zatem druga, dialektyczna strona relacji zachodzącej między składowymi elementami idei prawa. Okazuje się bowiem, że z jednej strony rywalizują one z sobą, z drugiej jednak warunkują swoje istnienie czy też — by nie uogólniać zbyt łatwo - w tym przynajmniej wypadku stało się tak, że całkowity zanik jednej z nich okazał się zarazem zanikiem pozostałych. Dlatego Radbruch może twierdzić, że akty prawne III Rzeszy nie tyle były rażąco niesprawiedliwym prawem, ile nie były prawem w ogóle.

Formuła Radbrucha jako korekta porządku trzech składników prawa oznacza wzmocnienie pozycji idei sprawiedliwości przy jednoczesnym odwrocie od ujmowania jej wymogów jako w pełni relatywnych. Sprawiedliwość jest teraz łączona z ideami praw człowieka oraz elementarnym wyczuciem aksjologicznym ${ }^{57}$. Prawa człowieka traktowane są tu już jako istotny element zachowania demokracji, który nie może być negowany przez powołanie się na zachowanie samych procedur demokratycznych ${ }^{58}$. Trzeba jednak podkreślić, że pewność prawa, mimo przewartościowania, wciąż pozostaje bardzo ważnym elementem składowym idei prawa $\mathrm{i}$ - jak widzieliśmy w przytoczonych słowach, traktujących o potrzebie zachowania elementów myślenia pozytywistycznego - w zwykłych sytuacjach ma ona znaczenie rozstrzygające. W literaturze zwraca się także uwagę, że Radbruch w swojej powojennej koncepcji osłabił również znaczenie celowości prawa ${ }^{59}$.

\section{Zarzuty Harta}

Przejdźmy teraz do zarzutów postawionych przez Harta $^{60}$. Przedstawiona przez niego krytyka jest przez komentatorów różnie oceniana i strukturyzowana ${ }^{61}$. Na użytek niniejszego tekstu wyróżniam dwa podstawowe argumenty obecne w rozważaniach Harta, zdając sobie przy tym sprawę, że nie jest to jedyny możliwy sposób porządkowania tej kwestii. Pierwszy z argumentów możemy określić jako pojęciowy, drugi zaś jako empiryczny.

55 G. Radbruch, Projekt..., s. 225-226.

56 G. Radbruch, Pięć minut..., s. 242. Zob. też idem, Ustawowe..., s. 250.

57 G. Radbruch, Ustawa..., s. 36.

58 Zob. J. Zajadło, Radbruch..., s. 165.

59 Zob. T. Chauvin, op. cit., s. 35-39.

60 Zob. H.L.A. Hart, Pozytywizm i oddzielenie..., s. 72-77.

61 R. Alexy, op. cit., s. 38-49; T. Mertens, op. cit., s. 195-198; F. Haldemann, Gustav Radbruch vs. Hans Kelsen: A debate on nazi law, „Ratio Juris” 18, 2005, z. 2, s. 170-172; J. Zajadło, Formuła Radbrucha. Filozofia..., s. 202-212. 
Argument pojęciowy polega na wskazaniu, że nie należy mieszać problemu istnienia prawa z zagadnieniem jego przestrzegania. Pytanie o to, czy jakaś regulacja jest prawem, nie determinuje bowiem odpowiedzi na pytanie, czy prawo to powinno być respektowane. Pierwsza kwestia jest problemem prawnym, druga zaś moralnym. Hart mocno przy tym podkreśla, że pozytywistyczna idea pojęciowej separacji prawa i moralności nie przesądza o istnieniu i zakresie moralnego obowiązku posłuszeństwa prawu ${ }^{62}$. Brytyjski filozof przypomina, że jakkolwiek zwykle przyjmuje się, iż istnieje coś takiego jak wynikające z szacunku dla własnej społeczności moralne zobowiązanie do podporządkowania się prawu, to zobowiązanie to ma charakter względny i jest uchylane w przypadku prawa wyjątkowo niegodziwego, które jednak nie traci wtedy statusu obowiązującego prawa $^{63}$. Decyzja o odmówieniu posłuszeństwa nie jest więc ugruntowana na jurydycznym rozpoznaniu walidacyjnym, lecz na moralnym sprzeciwie sumienia.

Jakkolwiek argument ten zdaje się wynikać przede wszystkim z ukierunkowanego na interesy poznawcze dążenia do zachowania klarowności pojęciowej, to uwikłany jest on również w pewne wskazywane przez Harta konsekwencje aksjologiczne, które mogą też być postrzegane jako dwa dodatkowe, osobne argumenty ${ }^{64}$. Mianowicie, po pierwsze, autor Pojęcia prawa wskazuje, że rezygnacja z klarownego odróżniania kwestii obowiązywania prawa od problematyki jego przestrzegania powoduje rozmazanie moralnego charakteru decyzji związanej z zachowaniem się wobec prawa oraz niepotrzebne uwikłanie jej w niejasne rozważania filozoficzne. Problem moralny zostaje tu — zdaniem Harta — przesłonięty przez niepotrzebne spekulacje teoretyczne. Po drugie, Hart wskazuje, że orzecznictwo karne opierające się na formule Radbrucha wprowadza do sposobu działania wymiaru sprawiedliwości pewną nieszczerość. W istocie bowiem jest on ukrytą formą retroaktywnej odpowiedzialności karnej. Zdaniem Harta, zamiast stosować tę formułę, uczciwiej byłoby postawić dylemat między niekaraniem pozostających na usługach hitlerowskiego reżimu urzędników, morderców i donosicieli z jednej strony oraz wprowadzeniem retroaktywnej penalizacji z drugiej, a następnie wskazać racje i społeczne koszty wybranego rozwiązania. Warto przy tym odnotować, że ów element ukrytej strategii wskazywany jest czasem jako najtrafniejszy ze wszystkich aspektów Hartowskiej krytyki ${ }^{65}$.

Oprócz zarysowanego argumentu pojęciowego w rozważaniach Harta istotna jest jeszcze racja odmiennej natury, którą okresliłem jako argument empiryczny. Zostaje on wysłowiony w następujący sposób:

Nie można czytać bez sympatii gorącego wezwania Radbrucha do większego otwarcia się niemieckiej świadomości prawnej na wyzwania moralności i jego protestu, że było tego zbyt mało w niemieckiej tradycji prawnej. $\mathrm{Z}$ drugiej strony mamy tutaj do czynienia z niezwykłą

62 H.L.A. Hart, Problemy filozofii prawa, [w:] idem, Eseje..., s. 117.

63 Zob. P. Kamela, Prawo i moralność w koncepcjach H.L.A. Harta, Torun 2008, s. 88.

64 Zob. J. Zajadło, Formuła Radbrucha. Filozofia..., s. 202-212.

65 Ibidem, s. 303-304. 
naiwnością w związku z poglądem, że brak wrażliwości w sprawach moralnych i poddanie się władzy państwowej w narodzie takim jak Niemcy wypływały z przekonania, iż prawo może być prawem w przypadku, gdy nie jest zgodne $\mathrm{z}$ minimum wymagań moralnych ${ }^{66}$.

Argument ten polega więc na stanowczym zanegowaniu tego, by uległość społeczeństwa niemieckiego wobec zbrodniczych rządów Hitlera miała swoje źródło w przyjęciu pozytywistycznego sposobu myślenia. Jakkolwiek mamy tu do czynienia z twierdzeniem o charakterze empirycznym, bo dotyczącym przebiegu pewnego złożonego procesu społecznego, to — jak się wydaje — jest ono nie tyle wynikiem studiów Harta nad historycznymi przemianami w międzywojennych Niemczech, ile raczej konsekwencją bardziej ogólnego założenia, dotyczącego relacji między teorią a praktyką społeczną. Fatalny rozwój wypadków w Niemczech nie był wynikiem jakiegoś wysoce niefortunnego splątania teoretycznego, lecz rezultatem skomplikowanych procesów psychosocjologicznych i tam też należy poszukiwać przyczyn triumfu faszyzmu. W tym duchu brytyjski filozof pisze:

Okropna historia, jakiej rzecz dotyczy, sugeruje raczej konieczność zbadania, dlaczego nacisk na hasło „prawo jest prawem” oraz odróżnienie prawa od moralności przyjęły taki złowrogi charakter w Niemczech, natomiast gdzie indziej, włącznie z samymi utylitarystami, współwystępowały z najbardziej oświeconym liberalizmem ${ }^{67}$.

Czy rzeczywiście Radbruch — były poseł Reichstagu, trzykrotny minister sprawiedliwości i jeden z pierwszych profesorów zwolnionych po dojściu Hitlera do władzy — był tak naiwny, jakby to wynikało z zarzutów Harta? W świetle dzieł samego Radbrucha oraz współczesnych komentarzy do nich jest jasne, że w pewnym zakresie doszło tu do nieporozumienia.

\section{Dyskusja argumentu empirycznego}

Oskarżenie pozytywizmu prawniczego o uczynienie prawników bezbronnymi wobec inwazji hitlerowskiego barbarzyństwa jest powtarzającym się elementem powojennych pism Radbrucha. Dziś najczęściej uznaje się, że teza ta, odczytywana dosłownie, jest zasadniczo fałszywa, co jednak — po pierwsze nie sprawia, że niczego nie można się z niej nauczyć, oraz — po drugie — nie przesądza o wartości pozostałych elementów formuły autora Filozofii prawa ${ }^{68}$. Przyjęło się też dzielenie tej tezy Radbrucha na dwa dopełniające się twierdzenia. Wedle pierwszego z nich pozytywizm prawniczy przyczynił się do skuteczności władzy Hitlera, wedle zaś drugiego jest on zarazem czynnikiem częściowo

${ }^{66}$ H.L.A. Hart, Pozytywizm i oddzielenie..., s. 74.

${ }^{67}$ Ibidem.

68 Zob. R. Dreier, S.L. Paulson, op. cit., s. CX; J. Zajadło, Formuła Radbrucha. Filozofia..., s. 295. 
„rozgrzeszającym” niemieckich jurystów z poddania się temu reżimowi ${ }^{69}$. Wspomniana falsyfikacja tezy Radbrucha najczęściej dotyczy obu tych aspektów. Argumentem rozstrzygającym są tutaj ustalenia historyczne, wedle których pozytywizm prawniczy nie był dominującym stanowiskiem ani w Republice Weimarskiej, ani tym bardziej w III Rzeszy ${ }^{70}$. Zauważmy jednak, że jest to inny argument niż używany przez Harta i jako taki nie wyjaśnia on sygnalizowanego nieporozumienia.

Kluczem do rozwiązania zagadki rzekomej naiwności Radbrucha jest zauważony już w polskiej literaturze trop, wedle którego myśliciel, mówiąc o zgubnym wpływie pozytywizmu prawniczego, miał najprawdopodobniej na myśli nie tyle stanowisko filozoficzno-prawne, ile pewien typ mentalności i związanych z nią postaw społecznych ${ }^{71}$. Rozwijając ten trop, można dodać, że w owym drugim znaczeniu mowa już nie o konstrukcjach teoretycznych, lecz o pewnych właściwościach tego, co Erich Fromm określa mianem „charakteru społecznego”, a co oznacza - w pewnym uproszczeniu - dominujący w danej zbiorowości i zarazem kształtujący poszczególne jednostki psychologiczny wzorzec osobowości ${ }^{72}$. Warto odnotować, że już w powstałym w 1910 roku Wstępie do prawoznawstwa Radbruch zwraca uwagę, że w jego kraju jest znacznie więcej jurystów, dla których prawo łączy się z dyscypliną, niż takich, dla których oznacza przede wszystkim zabezpieczenie wolności ${ }^{73}$. Pisze on o tym w takich między innymi słowach: „W Niemczech prawnik z poczucia porządku i ładu jest typem bardziej rozpowszechnionym. Odpowiada on pewnemu rysowi charakteru niemieckiego, któremu Niemcy wiele zawdzięczają (o tem nie potrzeba rozwodzić się wiele),

69 R. Dreier, S.L. Paulson, op. cit., s. CX. Analizie tych dwóch aspektów poświęcony jest w całości obszerny artykuł: S.L. Paulson, Lon L. Fuller, Gustav Radbruch, and the „positivist” theses, „Law and Philosophy” 13, 1994, nr. 3. Zob. też G. Radbruch, Ustawowe..., s. 251; H.P. Graver, op. cit., s. 162, 171-188.

70 Zob. M. Zmierczak, Pozytywizm prawniczy a prawnicy i prawo w Trzeciej Rzeszy - powojenna dyskusja niemieckich historyków i teoretyków prawa o przyczynach upadku prawa w czasach nazizmu, „Studia nad Faszyzmem i Zbrodniami Hitlerowskimi” 24, 2001; J. Zajadło, Radbruch..., s. $111-116$.

71 J. Zajadło, Formuła Radbrucha. Filozofia prawa..., s. 287 (oraz szerzej ibidem, s. 283295); U. Kosielińska-Grabowska, A. Grabowski, Teza o bezprawności ustawowej w konstytucyjnym państwie prawa, [w:] Demokracja. Teoria prawa. Sąownictwo konstytucyjne. Księga jubileuszowa dedykowana profesorowi zw. nauk prawnych Adamowi Jamrozowi z okazji pięćdziesięciolecia pracy zawodowej, red. M. Aleksandrowicz et al., Białystok 2018, s. 274.

72 Zob. E. Fromm, Ucieczka od wolności, przeł. O. i A. Ziemilscy, Warszawa 1999, s. 257276. Pojęcie „charakteru społecznego” omawiałem w innym miejscu — zob. P. Jabłoński, Szkic portretu przywódcy w oparciu o teorię Ericha Fromma, [w:] Gabinet luster. Psychoanalityczne krytyki poznania, red. I. Błocian, R. Saciuk, Toruń 2004, zwł. s. 46-53 (oraz podana tam literatura). Zob. też idem, O znaczeniu czynników osobowościowych w procesie stosowania prawa. Aplikacja perspektywy filozoficznej Ericha Fromma, [w:] Fromm - aplikacje, red. P. Jabłoński, R. Włodarczyk, Wrocław 2016.

73 G. Radbruch, Wstep..., s. 253-254. 
który jednak czasem dochodzi u nich do przesady, zagrażającej kulturze" ${ }^{\text {74 }}$. Najprawdopodobniej sporo racji ma Jerzy Zajadło, który łączy taki profil prawników, zwłaszcza zaś sędziów i szeroko ujmowanych urzędników, z gruntowną przebudową sądownictwa i służby administracyjnej, dokonaną w XIX wieku pod rządami Otto von Bismarcka ${ }^{75}$. Dodatkowym, potężnym impulsem odnawiającym i wzmacniającym rozwój autorytarnych rysów charakteru społecznego w Niemczech był ciąg wydarzeń następujących po 1914 roku, tworzący destrukcyjny splot czynników ekonomicznych, psychologicznych i socjologicznych, szczegółowo i przekonująco ukazanych w Ucieczce od wolności Ericha Fromma ${ }^{76}$.

Przy takiej reinterpretacji tezy Radbrucha nie tylko przestaje ona jawić się jako naiwna, ale też wydaje się dobrze korespondować z ustaleniami wspomnianego Fromma. Tym bardziej warto więc jeszcze wskazać dwa dodatkowe argumenty za poprawnością takiego odczytania intencji Radbrucha. Po pierwsze, zauważmy, że interpretacja ta pozwala pogodzić sformułowane przez niemieckiego filozofa prawa oskarżenie pod adresem pozytywizmu i wskazanie związanej z tym potrzeby zabezpieczenia społeczeństwa „przed przyszłym rozwojem pozytywizmu" 77 z podkreślaną zarazem przez niego w tym samym powojennym już czasie potrzebą zachowania pozytywistycznego sposobu myślenia. Po drugie, taka interpretacja pozwala też zrozumieć, dlaczego w kontekście oskarżenia pozytywizmu pojawiają się nie tylko prawnicy, lecz w niektórych sformułowaniach również „zwykły lud”78. Zauważmy, że gdyby przyjąć, że chodzi tylko o pewne stanowisko wypracowane w jurysprudencji, to odnoszenie tego do osób niebędących prawnikami byłoby niezrozumiałe.

Wydaje się jednak, że i taka reinterpretacja tezy Radbrucha byłaby wciąż jeszcze pewnym uproszczeniem. Pisze on bowiem też o zgubnym, ślepym posłuszeństwie wobec prawa jako o „wykwicie pozytywistycznej myśli prawniczej”79, co oznacza, że nie powinniśmy pozytywizmu jako teorii całkowicie uwalniać spod oskarżeń niemieckiego filozofa. Na tę potrzebę brania poważnie przestrogi Radbrucha przed niebezpieczeństwami paradygmatu pozytywistycznego zwracają uwagę Ralf Dreier i Stanley L. Paulson ${ }^{80}$, a w polskiej literaturze Lech Morawski ${ }^{81}$. Taki kierunek odczytywania formuły można wzmocnić, powołując się na główne dzieło jej autora. Otóż w Filozofii prawa Radbruch zwraca uwagę na Heglowską figurę „chytrości rozumu”, która — najogólniej mówiąc — polega na autonomizowaniu się wewnętrznej logiki jakiejś idei względem interesów,

\footnotetext{
74 Ibidem, s. 253.

75 J. Zajadło, Formuła Radbrucha. Filozofia..., s. 287-288.

76 Zob. E. Fromm, op. cit., s. 198-224.

77 G. Radbruch, Projekt..., s. 232.

78 G. Radbruch, Pięć minut..., s. 241. Por. idem, Ustawa ..., s. 31.

79 G. Radbruch, Pięć minut..., s. 244.

80 R. Dreier, S.L. Paulson, op. cit., s. CXI.

81 L. Morawski, op. cit., s. 99.
} 
które na ideę się powołały, a następnie redefiniującym współkształtowaniu sposobu rozumienia i artykulacji tych interesów: „Interes nie może powoływać się na idee, nie oddając się zarazem jej w służbę" $"$. Wydaje się więc, że Radbruchowi mogło też chodzić o pewną uproszczoną wersję teorii pozytywistycznej, która wywierała negatywny skutek na sposób rozumienia przez prawników rzeczywistości społecznej, w jakiej się znaleźli. Słusznie jednak wskazuje Jerzy Zajadło, że gdyby nawet przyjąć, iż Radbruchowi również chodziło o taką zwulgaryzowaną wersję teorii pozytywistycznej, a nie o same tylko postawy społeczne, to - po pierwsze - wciąż pozostaje kontrargument historyczny, dotyczący stosunkowo niskiej popularności pozytywizmu w czasie Republiki Weimarskiej i III Rzeszy oraz — po drugie — takie działanie „złej teorii” mogłoby być tylko wtórnym, a nie pierwotnym powodem wspomnianych postaw ${ }^{83}$. Raczej byłoby więc - jeśli dobrze rozumiem - wygodnym narzędziem do podtrzymywania uprzednio ukształtowanej postawy niż jej faktycznym źródłem. Warto też w tym kontekście zauważyć, że każda koncepcja filozoficzno-prawna, jak zresztą każda idea w ogóle, może być przedmiotem uproszczeń i wulgaryzacji, wykorzystywanych do złych celów, historia III Rzeszy zaś pokazała, że doktryny prawnonaturalne nie są pod tym względem bezpieczniejsze niż koncepcje pozytywistyczne.

\section{Dyskusja argumentu pojęciowego}

Także to, co zostało określone jako argument pojęciowy Harta, znalazło swoje kontrargumenty w literaturze przedmiotu, przy czym za kluczowego dyskutanta uchodzi tu Robert Alexy ${ }^{84}$. Po pierwsze więc, wskazuje się na to, że formuła Radbrucha nie prowadzi - wbrew temu, co twierdzi autor Pojęcia prawa - do maskowania problemu moralnego. Nie o to bowiem tam chodzi, by zanegować aspekt etyczny, lecz o to, by pokazać, że w pewnych sytuacjach staje się on również aspektem prawnym ${ }^{85}$. Koncepcja Radbrucha nie wprowadza zatem niejasności, a nawet gdyby ją wprowadzała, w sensie zastępowania ujęcia prostszego i bardziej czytelnego ujęciem bardziej złożonym, to prostota nie może być najważniejszym kryterium oceny teorii ${ }^{86}$. Po drugie, podkreśla się, że formuła Radbrucha tylko w wyjątkowych wypadkach przyznaje etyce moc walidacyjną, a zatem ewentualny problem zmniejszenia przejrzystości w relacjach między prawem

82 G. Radbruch, Filozofia..., s. 69.

83 J. Zajadło, Formula Radbrucha - geneza..., s. 32.

84 R. Alexy, op. cit., passim. Zob. też podobną do rozważań Alexy’ego analizę argumentów Harta, dokonaną przez Waltera Otta - J. Zajadło, Formuła Radbrucha. Filozofia..., s. 295-305 (oraz podana tam literatura).

85 R. Alexy, op. cit., s. 40.

86 Ibidem. 
a moralnością może mieć tu co najwyżej charakter marginalny ${ }^{87}$. Po trzecie, zwraca się uwagę, że stawiany przez Harta zarzut nieszczerości i związanej z nią ukrytej strategii, jakkolwiek oceniany jako poważny, możliwy jest do częściowego przynajmniej oddalenia. Można mianowicie i w tym kontekście odwołać się do wyjątkowego - a więc potwierdzającego, że zwykle należy działać w inny sposób - charakteru formuły, a także przypomnieć, że ani Radbruch, ani jego zwolennicy nie próbowali czynić tajemnicy z istnienia retroaktywnego wymiaru jej aplikacji ${ }^{88}$. Po czwarte zauważa się rownież, że wbrew temu, co twierdzi Hart, krytykowana formuła zawiera pewien potencjał oporu wobec destrukcyjnych dla porządku prawnego działań prawodawcy. Alexy wskazuje w tym kontekście na dwa argumenty. Pierwszy przedstawia w następujących słowach:

Gdy w praktyce prawniczej istnieje konsensus co do tego, że spełnienie określonych minimalnych postulatów sprawiedliwości stanowi konieczny warunek charakteru prawnego rozporządzeń władzy państwowej, to praktyka uzyskuje prawnicze, a nie tylko moralne podstawy, by móc się przeciwstawić aktom bezprawia ${ }^{89}$.

Dalej jednak Alexy dodaje, że nie należy przeceniać tego faktu:

Skutecznie działające państwo bezprawia jest bowiem w stanie w szybki sposób zniszczyć ten konsens przez akty indywidualnego szantażu, zmiany personalne czy wynagrodzenie tych, którzy są gotowi przystosować się. Można jednak założyć, że tego typu strategia może się nie powieść, zwłaszcza w łagodniejszych formach państwa bezprawia w ich początkowej fazie ${ }^{90}$.

Zauważmy, że jakkolwiek Alexy tego nie zaznacza, to w pierwszym z przytoczonych dopiero co cytatów nawiązuje implicite to Hartowskiej figury reguły uznania. Do tego wątku niebawem powrócimy.

Drugi z argumentów odwołuje się do tego, co obrońca formuły Radbrucha określa mianem „efektu ryzyka”. Ogólnie rzecz ujmując, polega on na tym, że przy popularności ujęcia niepozytywistycznego sędzia wydający „terrorystyczny wyrok karny, który opiera się na niegodziwej ustawie"91 wie, że ryzykuje więcej niż przy paradygmacie pozytywistycznym. W pierwszym bowiem przypadku może się spodziewać, że w razie upadku reżimu, któremu służy, będzie pociągnięty do odpowiedzialności za działanie bezprawne, w drugim zaś będzie odpowiadał tylko w razie uchwalenia retroaktywnej ustawy karnej, co jest zwykle bardzo problematyczne ${ }^{92}$.

Jako że argumentacja Alexy'ego jest polskiemu czytelnikowi dostępna, a nadto została już omówiona w literaturze, poprzestanę tutaj na przedstawionym przeglądzie najważniejszych elementów jego wywodów. Teraz chciałbym przejść

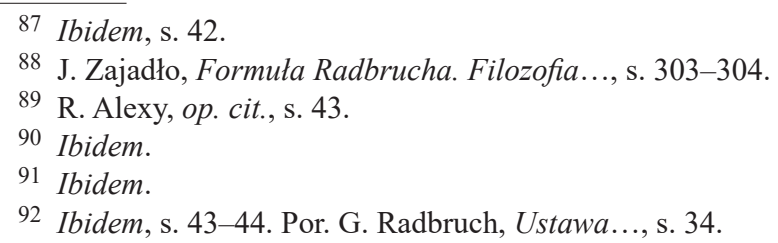


do wskazania i rozwinięcia tropu, który w literaturze pojawił się niedawno, a który wydaje się szczególnie interesujący. Prowadzi on bowiem do rekonfiguracji analizy sporu Harta z Radbruchem, w której pytanie o to, kto z nich ma rację, zastąpione jest pytaniem, w jakim zakresie prezentowane przez nich sposoby myślenia można $\mathrm{z}$ sobą pogodzić.

Warto przy tym zaznaczyć, że tropy pokazujące możliwość pogodzenia perspektywy Radbrucha z myśleniem przystającym do kanonów współczesnego pozytywizmu prawniczego są już obecne w polskiej literaturze. Dla przykładu Jan Woleński wskazuje na Hartowską koncepcję minimum prawa natury jako na swoisty teoretyczny pomost między brytyjskim i niemieckim klasykiem dwudziestowiecznej filozofii prawa ${ }^{93}$. Urszula Kosielińska-Grabowska i Andrzej Grabowski proponują z kolei przekonstruowanie formuły Radbrucha w taki sposób, który znosiłby napięcie między jej uznaniem a myśleniem pozytywistyczno-prawnym ${ }^{94}$. O ile więc $\mathrm{w}$ pierwszym wypadku mamy do czynienia z pewnym „ustępstwem" ze strony paradygmatu pozytywistycznego, o tyle w drugim korekta dokonywana jest przy koncepcji Radbrucha. Zdecydowanie dalej idzie Tomasz Kozłowski, który mówi o daleko idących podobieństwach między filozofią Radbrucha i Harta, poświęcając temu zagadnieniu odrębny artykuł ${ }^{95}$. Za łagodzeniem napięć między paradygmatem pozytywistycznym a konstrukcją zaproponowaną przez autora Pięciu minut filozofii prawa przemawia też poczyniona przez Jerzego Zajadłę konstatacja, wedle której myśl Radbrucha nigdy nie była ani konsekwentnie pozytywistyczna, ani zdecydowanie prawnonaturalna, balansując na granicy tych dwóch paradygmatów ${ }^{96}$.

Tutaj jednak chciałbym odwołać się do innego jeszcze stanowiska, jakie wyłania się z bardzo interesującej optyki zaproponowanej niedawno przez Briana H. Bixa. Autor ten, odnosząc się do sporu Harta z Radbruchem, proponuje postrzegać słynną formułę tego ostatniego jako pewną dyrektywę w zakresie podejmowania decyzji przez sądy, nie zaś jako teoretyczne twierdzenie o naturze prawa $^{97}$. Celem Radbrucha nie była analiza teoretyczna, to jest zbudowanie w duchu Harta teoretycznej mapy relacji między podstawowymi pojęciami wyznaczającymi ramę myślenia prawniczego, lecz odpowiedź na pytanie, jak powinien postąpić prawnik mający do czynienia ze skrajnie niesprawiedliwymi przepisami prawymi. Chodzi zatem o dwa zasadniczo różne, choć jakoś związane z sobą zadania.

93 J. Woleński, O formule Radbrucha, „Principia” 61-62, 2015, s. 13-17.

94 U. Kosielińska-Grabowska, A. Grabowski, op. cit., s. 278-282.

95 T. Kozłowski, Gustaw Radbruch jako twórca pozytywizmu aksjonormatywnego, [w:] Dobre prawo, złe prawo - w kręgu myśli Gustawa Radbrucha, red. P. Mochnaczewski, A. Kociołek-Pęksa, Warszawa 2009.

96 J. Zajadło, Radbruch..., s. 183.

97 B. Bix, Robert Alexy..., s. 149; idem, Radbruch's Formula and Conceptual Analysis, „The American Journal of Jurisprudence" 2011, z. 56, s. 56-57. 
Wkrada nam się tu figura filozoficzna o bardzo dobrze ugruntowanej tradycji (a i przez samego Radbrucha też czasem przywoływana), to jest Kantowskie zagadnienie relacji między rozumem teoretycznym a praktycznym ${ }^{98}$. Przypomnijmy, że wedle autora trzech Krytyk rozum praktyczny rozstrzyga to, czego nie rozstrzygnął rozum teoretyczny, ale musi on działać w ramach, jakie zostały mu przez ten rozum pozostawione. Dla przykładu wedle ustaleń rozumu teoretycznego istnieje możliwość wolności (a dokładniej możliwość możliwości wolności), więc rozum praktyczny, kierując się swoimi interesami, działa tak, jakby wolność istniała. Nie wyłamuje się on więc z ustaleń rozumu teoretycznego, ale dopełnia je w pozostawionym polu możliwości, stwarzając zarazem impuls zwrotny, który może być wykorzystany przez rozum teoretyczny. Element wyboru staje się zatem częścią procesu rozumienia.

Uzupełniając trop podpowiedziany przez Bixa zarysowaną wyżej figurą relacji między rozumem teoretycznym a praktycznym, możemy się zastanowić, czy nie da się w ten sposób uzgodnić perspektywy Harta i Radbrucha. Pierwszą rzeczą, na którą warto w tym kontekście zwrócić uwagę, jest to, że obydwaj ci myśliciele odrzucali w swoich rozstrzygnięciach model prawa jako bezwzględnie wiążącego rozkazu ${ }^{99}$. Co więcej, wydaje się że Hart idzie w tym zakresie znacznie dalej niż Radbruch. Odrzucenie modelu prawa jako rozkazu i zastąpienie go modelem prawa jako systemu reguł pierwotnych i wtórnych jest, jak wiadomo, rdzeniem Hartowskiego Pojęcia prawa. Warto od razu jednak dodać, że jakkolwiek Radbruch nie demontuje samej wizji prawa jako rozkazu, a bardziej tematyzuje zakres posłuszeństwa temu rozkazowi prawodawcy, to można znaleźć w jego Filozofi prawa fragmenty bardzo bliskie temu, o czym czytamy u Harta. Wedle Radbrucha w historyczno-socjologicznym ujęciu obowiązywania da się wyodrębnić dwa typy koncepcji: teorie władzy i teorie uznania. Teorie władzy — jak zauważa niemiecki filozof — mogą wytłumaczyć wzbudzanie w adresacie norm prawnych posłuszeństwa, ale już nie zobowiązania do posłuszeństwa; przymusu, ale nie powinności ${ }^{100}$. I dalej znajdujemy przykład, który mocno przypomina Hartowską figurę rozkazu bandyty, atakującą model prawa jako rozkazu:

Jak unaocznia trafne porównanie Merkela, bezwartościowy świstek nie nabierze wartości pieniądza przez to, że zmusi się kogoś do przyjęcia takiej „zapłaty”, celując do niego z pistoletu. Podobnie mało znaczyć będzie imperatyw dla osoby, która musi mu się poddać, szczękając ze strachu zębami; jeszcze mniej waży on dla kogoś, kto umie się odeń sprytnie uchylić. Jeśli prawo obowiązywałoby tylko dlatego, że stoi za nim siła, to przestałoby obowiązywać, gdyby siły zabrakło ${ }^{101}$.

98 Zob. P. Jabłoński, Relacja między Kantowska filozofia teoretyczna i praktyczna w świetle dwóch pierwszych „,Krytyk”, „Kwartalnik Filozoficzny” 2010, z. 3 (oraz podana tam literatura).

99 Zob. T. Kozłowski, op. cit., s. 42-43.

100 G. Radbruch, Filozofia..., s. 87.

101 Ibidem, s. 88. 
Dlatego też — jak raportuje Radbruch — teoria władzy przekształciła się w teorię uznania, przy czym nie chodzi o uznanie arbitralne i wolicjonalne „jako takie nie zależy od spontanicznej aktywności ducha, lecz przynależy do obszaru duchowej pasywności”" ${ }^{102}$. Jak czytamy dalej: „nie mamy w zasadzie żadnego wyboru, kiedy przychodzi nam uznać, że coś jest słuszne albo niesłuszne, piękne albo brzydkie, dobre albo złe, prawdziwe albo fałszywe"103, gdyż nie potrafimy „wyłączyć smaku, sumienia i rozsądku”" 104 .

Kolejny krok w zbudowaniu przejścia między teoretyczną perspektywą Harta a praktyczną Radbrucha łączy się ze wspomnianą regułą uznania. Otóż, jak wiadomo, jednym z trzech rodzajów wtórnych reguł w modelu Harta jest reguła uznania, rozstrzygająca o tym, co jest rozpoznawane jako prawo. Reguła ta — jak podkreśla Hart - jest elementem faktyczności, nie zaś czymś, co obowiązuje ${ }^{105}$. Autor Pojęcia prawa przyznaje explicite, że taka reguła może zawierać kryteria moralne ${ }^{106}$. Nie przeczy to tezie o rozdzieleniu prawa i moralności, ponieważ nie mówi się tu, że musi ona zawierać takie kryteria, a jedynie, że może. Hart w swojej teorii nie rozstrzyga kształtu reguły uznania w konkretnych porządkach prawnych, a tylko tworzy ogólny model teoretyczny. Nie wyklucza on więc, że w jakimś porządku prawnym zaistnieje taka reguła uznania, która będzie łączyć się $\mathrm{z}$ kryterium moralnym. W tym momencie kończy się praca rozumu teoretycznego, a zaczyna praktycznego. Formułę Radbrucha można bowiem potraktować jako wynikający z traumatycznej sytuacji historycznej apel rozumu praktycznego, by włączyć klauzule łączone z tezą odmowy lub tezą lekceważenia do reguły uznania współczesnych porządków prawnych. Jak pisze Radbruch, „milczenie rozumu teoretycznego staje się najdonioślejszym apelem do rozumu praktycznego"107. Rozum praktyczny proponuje więc rozstrzygnięcie tego, co pozostawia otwarte rozum teoretyczny.

Wydaje się, że częściowe potwierdzenie zasadności wskazywanego tu tropu znajdujemy u Waltera Otta ${ }^{108}$. Autor ten zauważa bowiem, że z formułą Radbrucha można pogodzić jeden tylko rodzaj pozytywizmu, mianowicie opierający się na teoriach uznania lub teoriach społecznego poczucia prawnego ${ }^{109}$ — wtedy status jakiejś ustawy jako prawa nie zależy tylko od względów formalnoprawnych.
102 Ibidem.
103 Ibidem.
104 Ibidem.
105 H.L.A. Hart, Pojęcie..., s. 151.

106 Ibidem, s. 331-332, 334-335. Por. H.L.A. Hart, Nowe wyzwanie dla pozytywizmu prawniczego, przeł. A. Grabowski, „Archiwum Filozofii Prawa i Filozofii Społecznej” 2014, z. 2. Zob. też A. Grabowski, Prequel do Hartowskiego Postscriptum - brakujace ogniwo $w$ debacie Harta z Dworkinem, „Archiwum Filozofii Prawa i Filozofii Społecznej” 2014, z. 2, s. 23.

107 G. Radbruch, Filozofia..., s. 19.

108 Pogląd Otta odtwarzam na podstawie J. Zajadło, Formuła Radbrucha. Filozofia..., s. 297 305 .

109 Ibidem, s. 297-298. 
Jakkolwiek następnie Ott, zestawiając optykę Radbrucha z Hartem, konstatuje, że prowadzą one do innych rozstrzygnięć, to wydaje się on pomijać wskazaną możliwość kształtu reguły uznania.

Pewnego rodzaju wsparcia proponowanego tu sposobu połączenia tych perspektyw można też doszukiwać się w podkreślanej w literaturze różnicy między ocenianiem formuly Radbrucha z perspektywy obserwatora stosowania prawa a ocenianiem jej z perspektywy wewnętrznej, a więc uczestnika argumentacji prawniczej, zwłaszcza zaś podejmującego decyzję sędziego ${ }^{110}$. Badacze zaznaczający tę różnicę wskazują, że znacznie łatwiej odrzucić tę formułę i przyjąć separację prawa względem moralności z perspektywy zewnętrznej. Jak zwraca uwagę Thomas Mertens, rekomendowane przez Harta rozdzielenie walidacji prawniczej i moralnej jest rozwiązaniem stosunkowo łatwym dla osoby nieuwikłanej w stosowanie prawa. Inaczej to wygląda w przypadku tych, którzy są zawodowo odpowiedzialni za rozpoznawanie prawa ${ }^{111}$. Ich decyzje podtrzymują bowiem lub przekształcają regułę uznania.

\section{Uwaga końcowa}

W literaturze zwraca się uwagę, że budowana przez Radbrucha filozofia prawa ma charakter antynomiczny, co oznacza nie tyle popadanie w wewnętrzne sprzeczności, ile odrzucanie myślenia dychotomicznego i włączanie w swój system obecnych $w$ rzeczywistości i myśleniu napięć ${ }^{112}$. Czasem cecha ta łączona jest z przypisywaną niemieckiemu myślicielowi chęcią kombinacji takiej teorii prawa, która będzie odpowiednia i na zwykłe, spokojne czasy, i na okresy burzliwe ${ }^{113}$. Jeśli $\mathrm{w}$ niniejszym sprawozdaniu $\mathrm{z}$ własnych prób przemyślenia sporu Harta z Radbruchem opowiedziałem się gdzieś bardziej po stronie Radbrucha, to chyba właśnie w próbie pokazania, że ciekawsze od odpowiadania na pytanie, który z nich ma rację, może być poszukanie możliwości częściowego chociaż pogodzenia tych pozornie sprzecznych perspektyw. Wydaje się to skądinąd również zgodne z duchem rozsądnej uwagi Harta, wedle której w większości argumentów długo obecnych w teorii prawa kryje się jakieś ziarno prawdy ${ }^{114}$.

110 R. Alexy, op. cit., s. 37-38; J. Zajadło, Formuła Radbrucha. Filozofia..., s. 296, 301-302.

111 Zob. T. Mertens, op. cit., s. 202-203.

112 Zob. H. Leawoods, op. cit., s. 489.

113 Ibidem, s. 491. Zob. też F. Haldemann, op. cit., s. 163.

114 H.L.A. Hart, Pojęcie..., s. 54. 


\section{Bibliografia}

Alexy R., W obronie niepozytywistycznej koncepcji prawa, przeł. L. Morawski, „Państwo i Prawo” 1993, z. 11-12.

Bix B., Robert Alexy, Radbruch's Formula, and the nature of legal theory, „Rechtstheorie” 2006, z. 37.

Bix B., Radbruch's formula and conceptual analysis, „The American Journal of Jurisprudence” 2011, z. 56.

Bogacz D., Formuła i filozofia prawa Gustava Radbrucha, „Ruch Prawniczy, Ekonomiczny i Socjologiczny" 2002, z. 3.

Chauvin T., Sprawiedliwość: między celowościa a bezpieczeństwem prawnym. Ewolucja pogladów Gustava Radbrucha, „Studia Iuridica” 37, 1999.

Dreier R., Paulson S.L., Wprowadzenie do filozofii prawa Radbrucha, [w:] G. Radbruch, Filozofia prawa, przeł. E. Nowak, Warszawa 2009.

Fromm E., Ucieczka od wolności, przeł. O. i A. Ziemilscy, Warszawa 1999.

Gizbert-Studnicki T., Grabowski A., Kilka uwag o niepozytywistycznej koncepcji prawa, [w:] Prawo a wartości. Księga Jubileuszowa Profesora Józefa Nowackiego, red. I. Bogucka, Z. Tobor, Kraków 2003.

Grabowski A., Prequel do Hartowskiego Postscriptum — brakujace ogniwo w debacie Harta z Dworkinem, „Archiwum Filozofii Prawa i Filozofii Społecznej” 2014, z. 2.

Graver H.P., Judges Against Justice. On Judges When the Rule of Law is Under Attack, Berlin-Heidelberg 2015.

Haldemann F., Gustav Radbruch vs. Hans Kelsen: A debate on nazi law, „Ratio Juris” 18, 2005, z. 2.

Hart H.L.A., Nowe wyzwanie dla pozytywizmu prawniczego, przeł. A. Grabowski, „Archiwum Filozofii Prawa i Filozofii Społecznej” 2014, z. 2.

Hart H.L.A., Pojęcie prawa, przeł. J. Woleński, Warszawa 1998.

Hart H.L.A, Pozytywizm i oddzielenie prawa od moralności, [w:] idem, Eseje z filozofii prawa, przeł. J. Woleński, Warszawa 2001.

Hart H.L.A., Problemy filozofii prawa, [w:] idem, Eseje z filozofii prawa, przeł. J. Woleński, Warszawa 2001.

Jabłoński P., O znaczeniu czynników osobowościowych w procesie stosowania prawa. Aplikacja perspektywy filozoficznej Ericha Fromma, [w:] Fromm - aplikacje, red. P. Jabłoński, R. Włodarczyk, Wrocław 2016.

Jabłoński P., Relacja między Kantowska filozofia teoretyczna i praktyczna w świetle dwóch pierwszych „Krytyk”, „Kwartalnik Filozoficzny” 2010, z. 3.

Jabłoński P., Szkic portretu przywódcy w oparciu o teorię Ericha Fromma, [w:] Gabinet luster. Psychoanalityczne krytyki poznania, red. I. Błocian, R. Saciuk, Torun 2004.

Kamela P., Prawo i moralność w koncepcjach H.L.A. Harta, Toruń 2008.

Kosielińska-Grabowska U., Grabowski A., Teza o bezprawności ustawowej w konstytucyjnym państwie prawa, [w:] Demokracja. Teoria prawa. Sąownictwo konstytucyjne. Księga jubileuszowa dedykowana profesorowi zw. nauk prawnych Adamowi Jamrozowi z okazji pięćdziesięciolecia pracy zawodowej, red. M. Aleksandrowicz et al., Białystok 2018.

Kozłowski T., Gustaw Radbruch jako twórca pozytywizmu aksjonormatywnego, [w:] Dobre prawo, złe prawo - w kręgu myśli Gustawa Radbrucha, red. P. Mochnaczewski, A. Kociołek-Pęksa, Warszawa 2009.

Leawoods H., Gustav Radbruch: An extraordinary legal philosopher, „Journal of Law and Policy” 2000, z. 2. 
Lubertowicz M., Lex iniustissima non est lex. Formula Gustava Radbrucha jako alternatywa dla międzynarodowego systemu ochrony praw człowieka, „Wrocławskie Studia Erazmiańskie”, z. 4. Prawa czlowieka - idea, instytucje, krytyka, red. M. Sadowski, P. Szymaniec, 2010.

Łącki P., Radbruch dzisiaj. Kilka uwag na marginesie nowego przektadu ,Filozofii prawa”, „Ruch Prawniczy, Ekonomiczny i Socjologiczny" 2011, z. 3.

Mertens T., Radbruch and Hart on the grudge informer: A reconsideration, „Ratio Juirs” 15, 2002, z. 2.

Morawski L., recenzja pracy Jerzego Zajadły, Formuła Radbrucha. Filozofia prawa na granicy pozytywizmu prawniczego i prawa natury, Gdańsk 2001, „Państwo i Prawo” 2002, z. 2.

Nowak E., Stowo od ttumacza, [w:] G. Radbruch, Filozofia prawa, przeł. E. Nowak, Warszawa 2009.

Oniszczuk J., Filozofia i teoria prawa, Warszawa 2012.

Paulson S.L., Lon L. Fuller, Gustav Radbruch, and the „positivist” theses, „Law and Philosophy” 13, 1994, nr. 3 .

Piechowiak M., Sprawiedliwe prawo - niesprawiedliwe wyroki. Uwagi na marginesie Arthura Kaufmanna koncepcji prawa do sprzeciwu wobec władzy, [w:] red. G. Baranowska et al., O prawach człowieka. Księa jubileuszowa Profesora Romana Wieruszewskiego, Warszawa 2017.

Radbruch G., Filozofia prawa, przeł. E. Nowak, Warszawa 2009.

Radbruch G., O celu prawa, przeł. K. Matuszewski, „Ruch Prawniczy, Ekonomiczny i Socjologiczny" 1937 , z. 3.

Radbruch G., Pięć minut filozofii prawa (dodatek 2), [w:] G. Radbruch, Filozofia prawa, przeł. E. Nowak, Warszawa 2009.

Radbruch G., Projekt postowia do „Filozofii prawa” (dodatek 1), [w:] G. Radbruch, Filozofia prawa, przeł. E. Nowak, Warszawa 2009.

Radbruch G., Ustawa i prawo, przeł. J. Zajadło, [w:] J. Zajadło, Radbruch, Sopot 2016.

Radbruch G., Ustawowe bezprawie i ponadustawowe prawo (dodatek 3), [w:] G. Radbruch, Filozofia prawa, przeł. E. Nowak, Warszawa 2009.

Radbruch G., Wstęp do prawoznawstwa, przeł. C. Znamierowski, Warszawa 1924.

Snarski T., Debata Hart-Fuller i jej znaczenie dla filozofii prawa, Gdańsk 2018.

Szyszkowska M., Europejska filozofia prawa, Warszawa 1995.

Woleński J., O formule Radbrucha, „Principia” 61-62, 2015.

Zajadło J., Formuła Radbrucha. Filozofia prawa na granicy pozytywizmu prawniczego i prawa natury, Gdańsk 2001.

Zajadło J., Formuła Radbrucha - geneza, treść, zastosowanie, „Państwo i Prawo” 2000, z. 6.

Zajadło J., Radbruch, Sopot 2016.

Zirk-Sadowski M., Wprowadzenie do filozofii prawa, Kraków 2000.

Zmierczak M., Pozytywizm prawniczy a prawnicy i prawo w Trzeciej Rzeszy — powojenna dyskusja niemieckich historyków i teoretyków prawa o przyczynach upadku prawa w czasach nazizmu, „Studia nad Faszyzmem i Zbrodniami Hitlerowskimi” 24, 2001. 